\title{
$H$-Gene-Mediated Resistance to Hessian Fly Exhibits Features of Penetration Resistance to Fungi
}

\author{
M. O. Harris, T. P. Freeman, J. A. Moore, K. G. Anderson, S. A. Payne, K. M. Anderson, and O. Rohfritsch
}

First, fourth, and sixth authors: Department of Entomology, NDSU Dept. 7650, P.O. Box 6050, and second, third, and fifth authors: Electron Microscopy Center, North Dakota State University, Fargo 58105; and seventh author: Institut de Biologie Moleculaire des Plantes, CNRS, Strasbourg, 67084, France (retired).

Accepted for publication 1 December 2009.

\begin{abstract}
Harris, M. O., Freeman, T. P., Moore, J. A., Anderson, K. G., Payne, S. A., Anderson, K. M., and Rohfritsch, O. 2010. H-gene-mediated resistance to Hessian fly exhibits features of penetration resistance to fungi. Phytopathology. 100:279-289.

Features shared by host-specific phytophagous insects and biotrophic plant pathogens include gene-for-gene interactions and the ability to induce susceptibility in plants. The Hessian fly shows both. To protect against Hessian fly, grasses have $H$ genes. Avirulent larvae die on $H$ gene-containing resistant plants but the cause of death is not known. Imaging techniques were used to examine epidermal cells at larval attack sites, comparing four resistant wheat genotypes ( $\mathrm{H} 6, \mathrm{H} 9, \mathrm{H} 13$, and $\mathrm{H} 26$ ) to a susceptible genotype. Present in both resistant and susceptible plants attacked by larvae were small holes in the tangential cell wall, with the
\end{abstract}

ABSTRACT size of the holes $(0.1 \mu \mathrm{m}$ in diameter) matching that of the larval mandible. Absent from attacked resistant plants were signs of induced susceptibility, including nutritive tissue and ruptured cell walls. Present in attacked resistant plants were signs of induced resistance, including cell death and fortification of the cell wall. Both presumably limit larval access to food, because the larva feeds on the leaf surface by sucking up liquids released from ruptured cells. Resistance was associated with several subcellular responses, including elaboration of the endoplasmic reticulum-Golgi complex and associated vesicles. Similar responses are observed in plant resistance to fungi, suggesting that "vesicle-associated penetration resistance" also functions against insects.

Additional keywords: arthropod, electron microscopy, gene-for-gene resistance, Mayetiola destructor, Triticum aestivum.
Discoveries made in the 1950s and 1960s set plant pathology and entomology on different paths, the former devoting more attention to genetics $(21,22)$ and the latter to ecology and evolution $(18,23)$. This is now changing. A system-wide approach seeks to find unifying themes in plant resistance in addition to unique features of individual plant-parasite interactions (88). A good place to look for unifying themes is among pathogens and insects that share attack strategies or are targeted by specific types of plant resistance $(30,44,45,65,77,83)$.

One way that insects can resemble biotrophic pathogens is their ability to induce plant susceptibility. This means that, before sustained feeding occurs, the parasite does something to the plant to make it more susceptible than it was prior to attack. One example of this is when basal defense is suppressed by the parasite $(38,66,86,91)$. Another is when the parasite redirects the development of one or more cells (usually relatively undifferentiated cells) to create a novel cell type, referred to as a nutritive or nurse cell $(1,15,24,78,84)$. The strange outgrowths that occur alongside the nutritive or nurse cell are given different names (e.g., gall, leaf curl, tumor, cyst, or knot), depending on whether the parasite is a fungus, oomycete, bacterium, nematode, insect, or mite $(1,15,24,78,84)$. The superior nutrition that the nutritive or nurse cells provide for the parasite occurs at the expense of the plant (45). This is because the redirected cell or tissue functions as a nutrient sink $(11,71)$, competing for resources that normally would be allocated to plant growth and reproduction $(29,49,88)$. Creation of the novel cell or cells by the parasite probably requires reprogramming of the plant genome (57) but

Corresponding author: M. O. Harris; E-mail address: Marion.Harris@ndsu.edu

doi:10.1094/PHYTO-100-3-0279

(C) 2010 The American Phytopathological Society how this occurs is generally not known; an exception is the reprogramming achieved by the crown gall, Agrobacterium tumefaciens (93).

Gene-for-gene interactions are another feature that can be shared by phytophagous insects and plant pathogens. A small number of insect species, mostly gall midges or aphids, have been shown to have an avirulence (Avr) gene that matches a major resistance $(R)$ gene found in a host plant $(8,36,52,56)$. Unlike pathogen-plant gene-for-gene interactions (6), the $R$ and $A v r$ genes involved in insect-plant interactions have not been identified. For the present, this limits the degree to which genefor-gene interactions can be compared across insects and pathogens. For the future, wheat may be a good system for making such comparisons. It is attacked by at least six parasites exhibiting gene-for-gene interactions $(1,6,8,36)$. Three are fungal species in the genus Puccinia and three are insects, including two aphids and a gall midge.

The Hessian fly, Mayetiola destructor Say, is the gall midge attacking wheat that shows classical gene-for-gene interactions (36). A serious pest of bread and durum wheat in many of the important wheat-growing regions of the world, the Hessian fly also attacks grasses in 16 other genera, including ancestors of wheat. The $H$-gene-containing resistant cultivars that have controlled Hessian fly populations for over 50 years were created using traditional wheat-breeding techniques (8). In some cases, the $H$ gene has been defeated 5 to 8 years after being deployed, presumably via selection of virulent Hessian fly genotypes in agricultural fields (31). Studies of gene-for-gene interactions between Hessian-fly $A v r$ genes and grass $H$ genes, originally demonstrated using classical Mendelian genetics (26), currently are proceeding along the same lines taken by plant pathologists (17). Identification of Hessian fly $A v r$ genes and wheat $H$ genes are expected in the near future (79). 
In addition to gene-for-gene interactions, the Hessian fly larva also induces susceptibility in host plants. Imaging studies revealed two features of induced susceptible plants (35): ruptured cell walls and a nutritive tissue comprising epidermal and mesophyll cells. Ruptured cell walls permit delivery of cell contents to the leaf surface, where the larva feeds by sucking up liquid cell contents (69). If the ruptured cells are nutritive, the liquids delivered to the larva are nutritionally enriched. It is not known whether ruptures are a direct result of effectors placed in the cell wall by the Hessian fly larva or result from a cellular process set in motion by larval effectors (e.g., autophagy). Larval-attacked plants change dramatically during induced susceptibility, especially in terms of carbon/nitrogen metabolism $(73,92)$. Induced susceptibility devastates the wheat plant: seedling growth essentially stops and resumes only if growth can be initiated from an axillary meristem (5). Attack during a later stage of plant development (e.g., stem elongation) does not kill the plant but results in a smaller seed head and smaller seed of reduced quality (8). Resistance via wheat $H$ genes prevents these adverse growth effects and also kills avirulent larvae (5). The reason for larval death on $H$-gene-containing resistant plants is not known.

Based on knowledge of gene-for-gene interactions between plants and pathogens (6), results from our previous imaging study of susceptible responses (35), and molecular studies of wheatHessian fly interactions $(60,82)$, we predicted that $H$-gene-containing resistant plants are similar to susceptible plants in that they both exhibit induced responses soon after larval attack begins. However, we also predicted that induced responses associated with resistance are entirely different from induced responses associated with susceptibility (35). We made three other predictions: the larva's physical attack of susceptible and resistant plants begins in the same way, the cell wall is an important focus for induced resistance responses, and larvae are impacted by induced resistance soon after they begin their attack. The present study used imaging techniques to examine epidermal cells at larval attack sites, comparing four resistant wheat genotypes ( $\mathrm{H} 6, \mathrm{H} 9$, $H 13$, and $H 26$ ) to a susceptible genotype. Because different $H$ genes were studied, we were able to compare resistance responses across the four resistant genotypes. Hessian fly larvae attacking susceptible and resistant genotypes were measured at five different times, beginning just after the larva emerged from the egg and ending on the fourth day of attack.

\section{MATERIALS AND METHODS}

Plant genotypes. The five wheat genotypes used in the study are shown in Table 1 . Three of the resistant genotypes- $H 6, H 9$, and H13 - are near-isogenic with the susceptible control genotype 'Newton' (67), each $H$ gene having been backcrossed six times into Newton. The uniform genetic background of $H 6, H 9, H 13$, and Newton has been confirmed by comparing target region amplification polymorphisms (TRAP), with differences $<1 \%$ (S. $\mathrm{Xu}$, United States Department of Agriculture-Agricultural Research Service [USDA-ARS], unpublished data). Not being available as a near-isogenic line, $H 26$ resistant wheat was obtained as a breeding line (PI 572542) from the National Small Grains Collection in Aberdeen, ID. H26 is the focus of current mapping efforts (90) because virulence to this gene is absent from Hessian fly populations in North America, Syria, Morocco, and Kazakhstan (16). $H 9$ and $H 13$ are also considered useful in spite of a low frequency of virulence $(8,16,68)$. The frequency of virulence to $H 6$ is much higher.

Insect-plant interactions. Plants were grown under controlled conditions $\left(20 \pm 1{ }^{\circ} \mathrm{C}\right.$; light-and-dark cycle of 16 and $8 \mathrm{~h}$, respectively; $710 \mu \mathrm{mol} / \mathrm{m}^{2} / \mathrm{s}$ ) in a Conviron E8 Plant Growth Chamber (Conviron, Winnipeg, Canada) to the two-leaf stage and infested with the Hessian fly biotype 'Great Plains' (8). Our laboratory culture of this biotype has been tested repeatedly on $H 6, H 9, H 13$, and $H 26$ wheat genotypes over the past 7 years and has been consistently avirulent (i.e., all larvae die 3 to 5 days after initiating attack, and plants show minimal signs of attack $(4,5)$. For the Avr gene that matches the H6, H9, H13, or $H 26$ gene, the genetic nomenclature for the Great Plains Hessian fly biotype is $v H 6^{\mathrm{A}} / v H 6^{\mathrm{A}}, v H 9^{\mathrm{A}} / v H 9^{\mathrm{A}}, v H 13^{\mathrm{A}} / v H 13^{\mathrm{A}}$, and $v H 26^{\mathrm{A}} / v H 26^{\mathrm{A}}$, respectively (79). Each seedling was exposed to a single egg-laying female Hessian fly between the hours of 1200 and 1400, until the required numbers of eggs (20 to 50) were placed on the second leaf. Each female was exposed to only one plant. More than 50 Hessian-fly larvae can survive and grow on a single wheat seedling (89). After eclosion, neonate larvae migrated down the leaf blade, entered a protected zone between the sheaths of the second and third true leaves, and continued to move down to the base of the leaf, attacking the abaxial side of the third leaf within $1 \mathrm{~cm}$ of its base. Hessian fly larvae lose their mobility after molting to the second instar (25). At the time of initial larval attack, the first and second leaves were full grown but the third leaf had just emerged from the leaf sheath and, in plants without larvae, would grow another $17 \mathrm{~cm}$ over the next 6 days (5).

Microscopy techniques. The imaging techniques used for the current study were similar to those used by Harris et al. (35) to study responses of the susceptible genotype Newton to virulent Great Plains Hessian fly. Experimental design for the current study on responses of $H$-gene-containing resistant wheat to Hessian fly attack was a randomized complete block including five wheat genotypes (one susceptible and four resistant: $\mathrm{H6}, \mathrm{H} 9$, H13, or H26), two larval treatments (plants free of larvae and plants attacked by larvae), and replicated observations. Three blocks of plants were prepared, with each block consisting of 10 plants/treatment. Within each block, four plants per treatment were prepared for scanning electron microscopy (SEM), with the remaining six prepared jointly for transmission electron microscopy (TEM) and light microscopy.

Conclusions about the typical responses of resistant epidermal cells attacked by Hessian fly larvae were based on three criteria: (i) whether the response of cells of the resistant plant + larvae differed from the response of cells of the susceptible plant + larvae, (ii) whether the response of the cells of the resistant plant + larvae differed from that of the cells of the resistant plant without larvae, and (iii) whether the response of the cells of resistant plant + larvae was consistent within all sections of a single leaf sample, as well as across replicates of each plant-insect treatment. Representative SEM, TEM, and light micrograph images were chosen.

Leaf samples were prepared $78 \mathrm{~h}$ after the beginning of larval attack. In the previous study of susceptible plants (35), this was the time when rupture of the tangential cell wall was reliably

TABLE 1. Susceptible and resistant wheat, Triticum aestivum L. (genome AABBDD), used in imaging and Hessian fly growth studies

\begin{tabular}{|c|c|c|c|c|}
\hline Wheat & $H$ gene & Relationship to 'Newton' & Species origin of $H$ gene and its genome & Chromosome location of gene (references) ${ }^{\mathrm{a}}$ \\
\hline 'Newton' susceptible & $\ldots$ & $\ldots$ & $\ldots$ & $\ldots$ \\
\hline 'Flynn' resistant & H6 & Near-isogenic & Triticum turgidum subsp. durum (AABB) & 1AS $(27,47,54)$ \\
\hline 'Iris' resistant & $H 9$ & Near-isogenic & Triticum turgidum subsp. durum (AABB) & $1 \mathrm{AS}(47,54)$ \\
\hline 'Molly' resistant & $H 13$ & Near-isogenic & Aegilops tauschii Cosson (DD) & $6 \mathrm{DS}(55)$ \\
\hline PI 572542 resistant & $H 26$ & Not near-isogenic & Aegilops tauschii Cosson (DD) & 3DL (90) \\
\hline
\end{tabular}

${ }^{a}$ Numbers within parentheses are references for $H$ gene chromosome location. 
observed in SEM studies and when nutritive cells were seen in light and TEM studies. For each plant, the leaf sample was taken from a $1-\mathrm{cm}$ region at the base of the third leaf, just above the shoot apical meristem, where $>90 \%$ of larvae are found after twoleaf-stage wheat seedlings are exposed to egg-laying Hessian fly females. Tissue was collected underneath the heads of larvae and from a similar location in plants without larvae.

For SEM, the sample was fixed in $2.5 \%$ glutaraldehyde in phosphate buffer ( $\mathrm{pH} \mathrm{7.4)}$ at room temperature for at least $4 \mathrm{~h}$, dehydrated in an ethanol series (30 to 100\%), and critical-point dried (Autosamdri 810; Tousimis, Rockville MD). Dried specimens were attached to aluminum mounts with silver paint or carbon tape and sputter coated with gold or gold-palladium (Model SCD030; Balzer, Liechtenstein) before SEM examination of the abaxial leaf surface (JSM-6300; JEOL, Peabody MA).

For TEM and light microscopy, samples were fixed in cold $2.5 \%$ glutaraldehyde in phosphate buffer $(\mathrm{pH} 7.4)$ for $2 \mathrm{~h}$ or longer, rinsed in phosphate buffer, post fixed in $2 \%$ osmium tetroxide for $4 \mathrm{~h}$, and dehydrated in a graded acetone series (30 to $100 \%$ ). Samples were en-bloc stained in $70 \%$ acetone saturated with uranyl acetate during dehydration and embedded in eponaraldite epoxy resin. For TEM, the block was sectioned in three locations along the face of the leaf surface. This provided samples of three sets of cells near the head of the larva. Ultramicrotome (RMC MTXL, Tucson, AZ) sections were made to a thickness of 50 to $70 \mathrm{~nm}$ and stained with $2 \%$ lead citrate for 2 to $3 \mathrm{~min}$. The 10 to 25 sections taken at each location (multiple sections from the same adjacent epidermal cells) were transferred to five different TEM grids, examined for cellular responses, and photographed in TEM (JEM-100 CX II; JEOL). The same block was used for light microscopy, with thick sections $(1$ to $2 \mu \mathrm{m})$ taken adjacent to the three locations used for TEM sections and stained with $0.1 \%$ toluidine blue in $1 \%$ aqueous sodium borate. A compound light microscope (Eclipse E600; Nikon, Melville, NY) equipped with a confocal unit (CARV Confocal Cell Imaging System; Fryer Company, Bloomington, MN) was used to examine and photograph thick sections.

Measurements of larvae. To determine how larvae respond during the first days of attacking $\mathrm{H}$-gene-containing resistant plants, plants of the five genotypes were grown and infested as described previously. To sample larvae, we carefully pulled each leaf away from the rest of the plant and used a sable brush to remove larvae, which were all located on the abaxial surface within $2 \mathrm{~cm}$ of the base of the leaf. Larvae were positioned on a glass slide in a drop of water, covered with a coverslip, and viewed and photographed using the light microscope. Body length, from the top of the head to the longest point of the abdomen, was measured using CARV Imaging Software. Larval body movements were used to determine if the larva was living or dead.

There were five times when larvae were destructively sampled. The first group was sampled at 1500 to $1600 \mathrm{~h}$ when neonate larvae were eclosing from eggs placed on the leaf blade by the egg-laying female. After eclosion, the larva walks down the leaf blade and the leaf sheath to the base of the leaf, with this taking up to $14 \mathrm{~h}$ (58). The four other groups of larvae were sampled on the four days that followed the day of eclosion. These larvae were located at attack sites at the plant base and were sampled between 0900 and $1100 \mathrm{~h}$.

Data were checked for normal distribution and homogeneity of variance using O'Brien's test (72) and log transformed, if necessary, to achieve homogenous variances (larger variances were always associated with larger means). When variances were homogeneous, a one-way analysis of variance (ANOVA) (72) was used to test for effects of wheat genotype. When homogeneous variances could not be achieved by log transformation, a Welch ANOVA that does not require homogeneity of variances was used (72).

\section{RESULTS}

Microscopy studies. Larvae were found attacking the abaxial surface of the third leaf, within $1 \mathrm{~cm}$ of the leaf base, typically with the head facing down (Fig. 1A). The paired larval mandibles (Fig. $1 \mathrm{~B}$, arrows) were small, $\approx 0.1$ to $0.2 \mu \mathrm{m}$ in diameter and 1 to $2 \mu \mathrm{m}$ long.

On SEM, susceptible and resistant plants attacked by larvae were similar in that the outer cell walls of both showed small holes, $<0.4 \mu \mathrm{m}$ in diameter (Table 2). A difference was that only susceptible plants had cell walls that showed larger holes, 1 to $10 \mu \mathrm{m}$ in diameter (Table 2). The SEM image taken from a resistant plant (Fig. 1C) shows a series of small holes, each only 0.1 to $0.4 \mu \mathrm{m}$ in diameter. The SEM image taken from a susceptible plant (Fig. 1D, two arrows) again shows small holes $\approx 0.1 \mu \mathrm{m}$ in diameter. However, here the small holes are accompanied by a larger hole (rupture) with a diameter of $2 \mu \mathrm{m}$ (Fig. 1D).

On TEM, a small hole in the tangential wall (Fig. 2, w) beneath the larva (Fig. 2, L) was observed on $H 13$ resistant plants (Fig. 2, arrow). This hole is small $(0.15 \mu \mathrm{m}$ wide and $0.27 \mu \mathrm{m}$ deep $)$, matching the approximate size of the larval mandible, and does not appear to traverse the wall. The material that fills the hole (arrow) appears similar in electron density and particle morphology to the material seen between the cell wall and plasma membrane (arrowhead).

Resistant and susceptible plants differed in that nutritive tissue was present in susceptible plants but absent from resistant plants (Table 2). Using light microscopy, susceptible plants (Fig. 3A) showed a nutritive tissue comprising both epidermal and mesophyll cells, with the nutritive cells characterized by increased cytoplasmic staining $(11,35,71)$. The four resistant genotypes did not show cytoplasmic staining (Fig. 3B).

On TEM, resistant plants attacked by larvae failed to show the three cell types that were found in susceptible plants attacked by larvae (Table 3). The three susceptible cell types can be contrasted with the normal meristematic epidermal cell of the abaxial leaf sheath, a cell type that is typical of susceptible and resistant plants free of larvae (Fig. 4A). Susceptible Type One was an epidermal cell that did not transition to a nutritive cell but, instead, lysed and ruptured its tangential wall (Fig. 4B, arrows) to spill degraded cell contents onto the leaf surface (Fig. 4B). Susceptible Type Two was a classic nutritive cell (Fig. 4C) found in both epidermal and mesophyll layers: cytoplasm appeared dense due to increased numbers of organelles, especially mitochondria (Fig. 4C, arrows), proplastids, and Golgi. In the nucleus (Fig. 4C, N), chromatin appeared clumped, and the nuclear envelope was invaginated rather than smooth. Vacuoles had increased in number but were smaller in size. Susceptible Type Three (Fig. 4D) was a nutritive cell with its contents now broken down and its wall thinned, both at the tangential wall (Fig. 4D, diagonal arrow) and the wall shared with the adjacent epidermal cell (Fig. 4D, horizontal arrow).

Instead of the three susceptible cell types, the four resistant genotypes showed two different cell types (Table 3), with these types presumably representing features of induced resistance. Resistant Type One cells are represented by the epidermal cell at the far left in Figure 5A (the cell that lies directly below the letter A), the mesophyll cells directly below the three epidermal cells in Figure 5A, and the epidermal cell in Figure 5B. These apparently healthy and activated epidermal and mesophyll cells showed an altered nucleus $(\mathrm{N})$, swollen mitochondria $(\mathrm{m})$, a thickened cell wall (arrows), increased vacuolation (V), and increased endoplasmic reticulum (er) and Golgi. Details of this are shown in Figure 6 and listed in Table 3. Golgi bodies (Fig. 6A, arrowheads) were increased in number and apparent activity, with groups of small vesicles lined up next to the Golgi. Endoplasmic reticulum (er) (Fig. 6A, er) volume was increased (Fig. 6B, epidermal cell at lower left). Mitochondria (m) appeared swollen (Fig. 6C). 
Paramural spaces (PS) of varying size (Fig. 6A, arrow; and Fig. 6B) were observed between the tangential wall (W) and the plasma membrane (PM) and were filled with granular material (Fig. 6A to C). Finally, the tangential cell wall (W) was characteristically thickened (Fig. 6A to D) and showed pockets of material within the matrix of the wall (Fig. 6B, arrow). Excess membrane material (MM) was observed directly beneath the tangential cell wall (Fig. 6D).

Resistant Type Two cells appeared to be dying (Table 3). This cell type is best illustrated in Figure 5A by the epidermal cell on the far right, directly beneath the larva. This cell type showed cell-wall fortification, a large paramural space (PS) due to plasmolysis (separation between the wall and the plasma membrane), breakdown of the cytoplasm (C), and lysis of cytoplasmic organelles. The middle epidermal cell in Figure
5A shows many of the same features, although not to the same degree as the cell on the right. Neither of these two cells showed cell wall ruptures or loss of cytoplasmic material to the leaf surface.

Larval growth differs on susceptible and resistant plants. A model incorporating plant genotype, the time larvae had been at attack sites, and the interaction between genotype and time explained a significant proportion of the variation in larval size $\left(\mathrm{F}_{24,1218}=132.42, P<0.001\right)$. The effect of plant genotype $\left(\mathrm{F}_{4,1218}=\right.$ $233.41, P<0.001)$, effect of time at attack sites $\left(\mathrm{F}_{4,1218}=40.76\right.$, $P<0.001)$, and the interaction between plant genotype and time $\left(\mathrm{F}_{16,1218}=80.62, P<0.001\right)$ were all significant. Subsequent analyses (Table 4) explored differences among plant genotypes for a particular day, as well as differences across time for each of the five wheat genotypes.
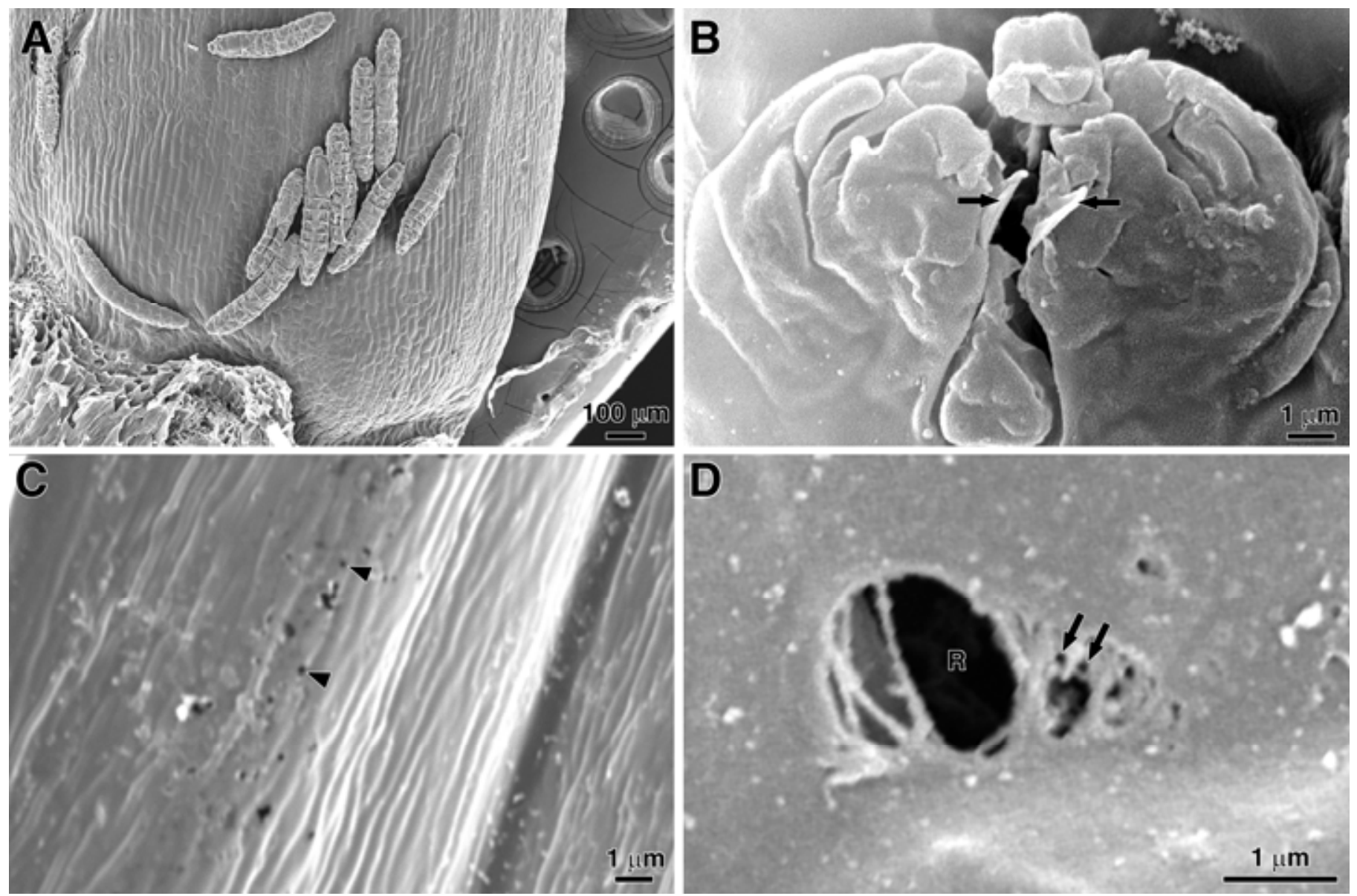

Fig. 1. Hessian-fly larvae and sites of larval attack on the leaf surfaces of resistant and susceptible wheat genotypes, scanning electron microscopy. A, Hessian fly larvae at attack sites, abaxial surface at base of third leaf. B, Mouthparts of a Hessian fly larva. Note the mandibles (arrows) have a diameter of $<0.1 \mu \mathrm{m}$. C, Abaxial leaf surface of a resistant-genotype plant attacked by avirulent larvae. Note the small holes (arrowheads) in the outer tangential epidermal wall. D, Abaxial leaf surface of the susceptible-genotype plant attacked by virulent larvae. Note the two holes (arrows) that match the diameter and spacing of the paired larval mandibles and the adjacent large rupture $(\mathrm{R})$ in the wall of the epidermal cell.

TABLE 2. Evidence for differing responses of larval-attacked susceptible and $H$-gene-containing resistant wheat ${ }^{\mathrm{a}}$

\begin{tabular}{|c|c|c|c|c|c|c|}
\hline \multicolumn{2}{|c|}{ Plant-insect interaction } & \multicolumn{2}{|c|}{ SEM evidence cell walls ${ }^{\mathrm{b}}$} & \multicolumn{2}{|c|}{ TEM and light evidence ${ }^{c}$} & \multirow{2}{*}{$\begin{array}{l}\text { Larval growth } \\
\text { at } 78 \mathrm{~h}^{\mathrm{d}}\end{array}$} \\
\hline Plant treatment & Larval treatment & Small holes & Large holes & Nutritive cells & Cell walls & \\
\hline Susceptible & (-) Larvae & Absent & Absent & Absent & Normal & NA \\
\hline Susceptible & (+) Larvae & Present & Present & Present & Thinned & Size doubles \\
\hline Resistant & (+) Larvae & Present & Absent & Absent & Reinforced & Little or no growth \\
\hline
\end{tabular}

${ }^{a}$ Four resistant wheat genotypes $(H 6, H 9, H 13$, and $H 26)$ showed similar responses.

${ }^{\mathrm{b}} \mathrm{SEM}=$ scanning electron microscopy. Holes in wall: Small $=<0.4 \mu \mathrm{m}$ in diameter and Large $=1$ to $10 \mu \mathrm{m}$ in diameter.

${ }^{c}$ TEM $=$ transmission electron microscopy for nutritive cells and cell walls.

${ }^{\mathrm{d}}$ Evidence from measures of larval growth at $78 \mathrm{~h}$; NA indicates that no measurement was made because larvae were not present. 
Within each time interval, a comparison of larval growth across the five wheat genotypes (Table 4, ANOVA at the bottom of each column) showed that larvae started out being the same size but differed thereafter (Table 4 ). At $\approx 6 \mathrm{~h}$ after arriving at attack sites at the leaf base, larvae on the susceptible genotype Newton were 5 to $8 \%$ larger than larvae on resistant genotypes. At 30, 54, and $78 \mathrm{~h}$, larvae on susceptible plants were 20,80 , and $230 \%$ bigger, respectively, than larvae on resistant plants.

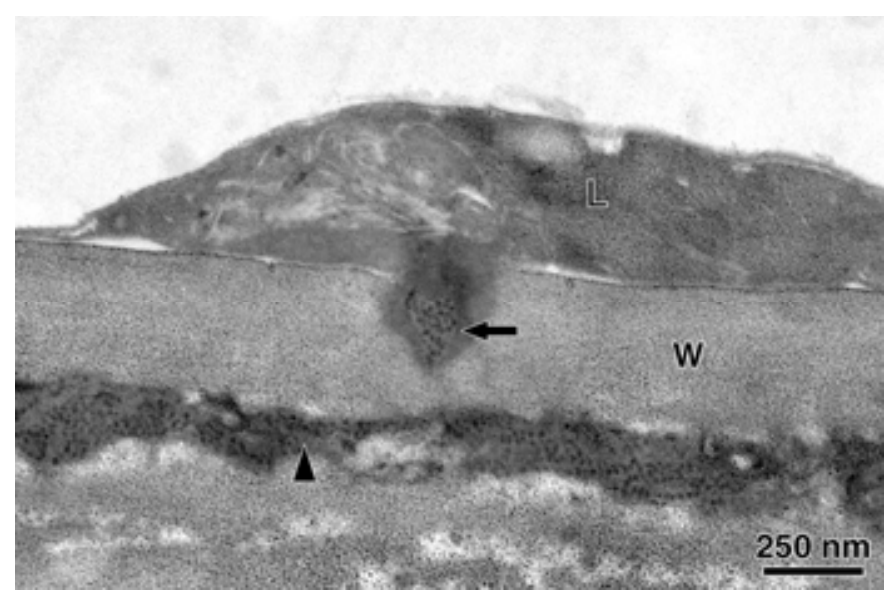

Fig. 2. Transmission electron microscopy image of a small hole (arrow) in the tangential wall (W) of an epidermal cell of $H 13$ resistant wheat beneath a Hessian-fly larva (L). Note the similar staining features of the material (arrow) within the cell wall and the material located between the wall and the plasma membrane (arrowhead).
For each plant treatment, comparisons of larval growth over time (Table 4, ANOVA appears at far right of each row) showed that susceptible plants allowed larvae to grow in a sustained manner whereas resistant plants did not. Larvae on susceptible plants increased in body length at each measurement. In contrast, larvae on $H 9, H 13$, and $H 26$ resistant genotypes lost 7 to $11 \%$ of their body length between 6 and $54 \mathrm{~h}$. Larvae on $H 6$ exhibited an intermediate response, increasing by $14 \%$ at 6 to $54 \mathrm{~h}$ but, by 78 $\mathrm{h}$, had failed to grow further. Regardless of whether the plant was susceptible or resistant, most larvae were still alive when the final measurement was taken. At $78 \mathrm{~h}$, the proportion of larvae that were still living was similar for the susceptible (99\%), H6 (94\%), $H 9$ (93\%), H13 (89\%), and H26 (98\%) $\left(\chi^{2}=7.69\right.$, df $=4,274$, $P=0.11)$.

\section{DISCUSSION}

Our study began by asking: do Hessian fly larvae begin their attack on resistant and susceptible plants in the same way? This is a prediction of the biochemical model of gene-for-gene interactions. Regardless of whether the plant is resistant or susceptible, the parasite is expected to physically attack the plant cell, with the physical attack followed by chemical attack via secretion of effectors onto or into the cell $(6,14,62)$. This appears to be the case for Hessian fly: in both resistant and susceptible plants, small holes were found in the tangential wall of epidermal cells (Fig. 1C and D). The holes were similar in size to those observed in a previous study of susceptible plant responses (35) and matched the dimensions, as well as the spacing, of the larva's paired mandibles (Fig. 1B). The hole found in the tangential wall of $H 13$ (Fig. 2) was of a similar size, suggesting that the larval mandible
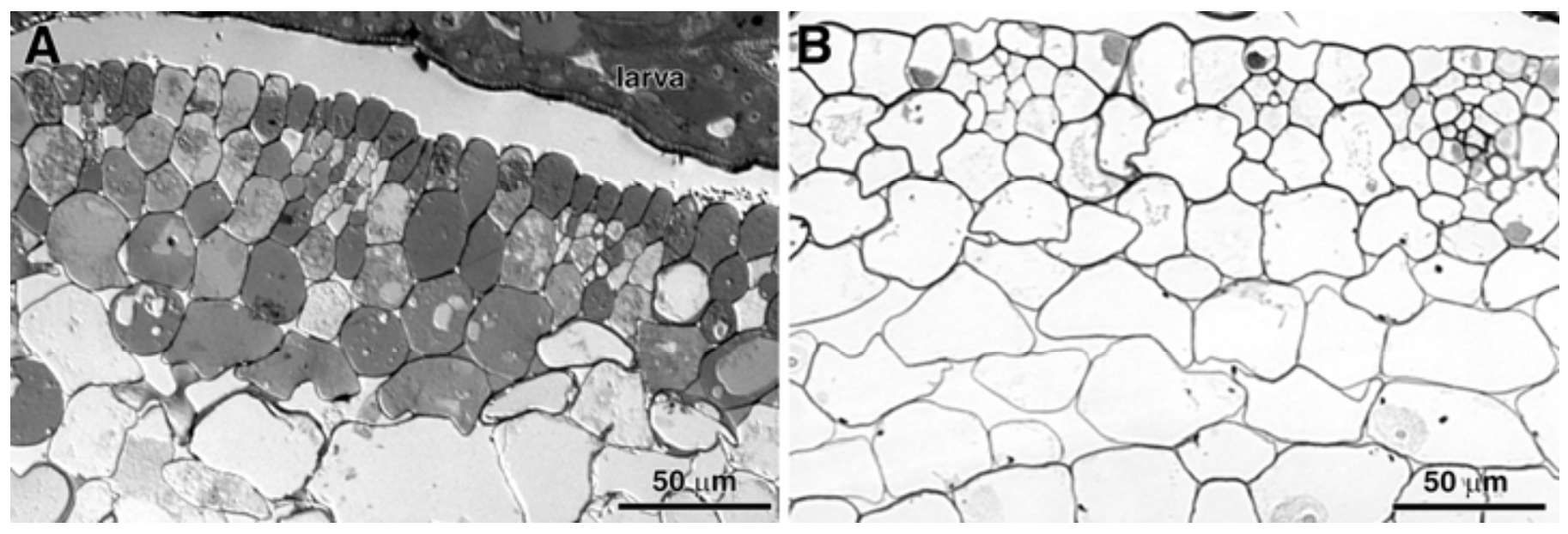

Fig. 3. Cross section of the abaxial surface of wheat leaves attacked by Hessian fly larvae. Light microscopy. A, Susceptible wheat genotype. Darker-stained epidermal and mesophyll cells constitute the nutritive tissue. The larva is shown at the top of the image. B, Resistant wheat genotype. No nutritive tissue is present.

TABLE 3. Cell types in larval-attacked susceptible wheat and $H$-gene-containing resistant wheat ${ }^{\mathrm{a}}$

\begin{tabular}{|c|c|c|c|c|c|}
\hline \multirow[b]{2}{*}{ Subcellular feature } & \multicolumn{3}{|c|}{ Susceptible } & \multicolumn{2}{|c|}{ Resistant } \\
\hline & $\begin{array}{c}\text { Type One } \\
\text { (nonnutritive) }\end{array}$ & $\begin{array}{c}\text { Type Two } \\
\text { (nutritive cell) }\end{array}$ & $\begin{array}{c}\text { Type Three } \\
\text { (nutritive cell) }\end{array}$ & $\begin{array}{c}\text { Type One } \\
\text { (nonnutritive) }\end{array}$ & $\begin{array}{c}\text { Type Two } \\
\text { (nonnutritive) }\end{array}$ \\
\hline Organelles & Lysed & $\begin{array}{l}\text { Uneven nuclear envelope, increased } \\
\text { mitochondria, increased } \\
\text { proplastids, increased number } \\
\text { Golgi, increased rough ER, } \\
\text { smaller vacuoles, more vacuoles }\end{array}$ & Lysed & $\begin{array}{l}\text { Swollen mitochondria, } \\
\text { elaboration of ER, increased } \\
\text { number Golgi, increased } \\
\text { number vesicles, smaller } \\
\text { vacuoles, more vacuoles }\end{array}$ & Lysed \\
\hline Cell wall & $\begin{array}{l}\text { Thinned wall, } \\
\text { ruptures }\end{array}$ & Normal wall, no ruptures & $\begin{array}{l}\text { Thinned wall, ruptures, } \\
\text { plasmodesmata enlarged }\end{array}$ & $\begin{array}{l}\text { Reinforced wall, no ruptures, } \\
\text { pockets in wall }\end{array}$ & $\begin{array}{l}\text { Reinforced wall, } \\
\text { no ruptures }\end{array}$ \\
\hline Plasma membrane & $\begin{array}{l}\text { Adheres to } \\
\text { wall }\end{array}$ & Adheres to wall & Adheres to wall & $\begin{array}{l}\text { Separates from wall, material } \\
\text { in space, membrane masses }\end{array}$ & $\begin{array}{l}\text { Separates from wall, } \\
\text { material in space }\end{array}$ \\
\hline
\end{tabular}

${ }^{a}$ Four resistant wheat genotypes $(H 6, H 9, H 13$, and $H 26$ ) showed similar responses. 
may not be long enough to traverse the tangential cell wall. Morphological, genetic, and biochemical studies all point to the Hessian-fly mandible acting as a delivery system for various effectors that are secreted by the salivary glands $(12,37,79,80)$. Given that initial attack of susceptible and resistant plants began the same way, with the larva using its mandibles to attack the cell wall, the next question was: how did the response of resistant plants differ?

A major difference was that resistant plants did not exhibit features of induced susceptibility (Tables 2 and 3). The features of induced susceptibility that were absent from resistant plants included large holes in the outer cell wall (Figs. 1D and 4B), ruptured non-nutritive cells (Fig. 4B; Table 3, Susceptible Type 1), alteration of cells to form nutritive tissue (Figs. 3A and 4C; Table 3, Susceptible Type 2), and lysed nutritive cells with a thinned wall (Fig. 4D; Table 3, Susceptible Type 3). The larva's inability to induce these susceptible features in resistant plants is presumably why Hessian fly interactions with susceptible and resistant plants are so different. The growth of susceptible plants and the growth of resistant plants diverge 2 to 3 days after larval attack begins $(4,5)$, which also is the time that is needed to induce the susceptible plant to create the nutritive tissue and rupture the walls of nutritive cells (35). All insects, mites, nematodes, and pathogens that induce feeding cells in susceptible plants need
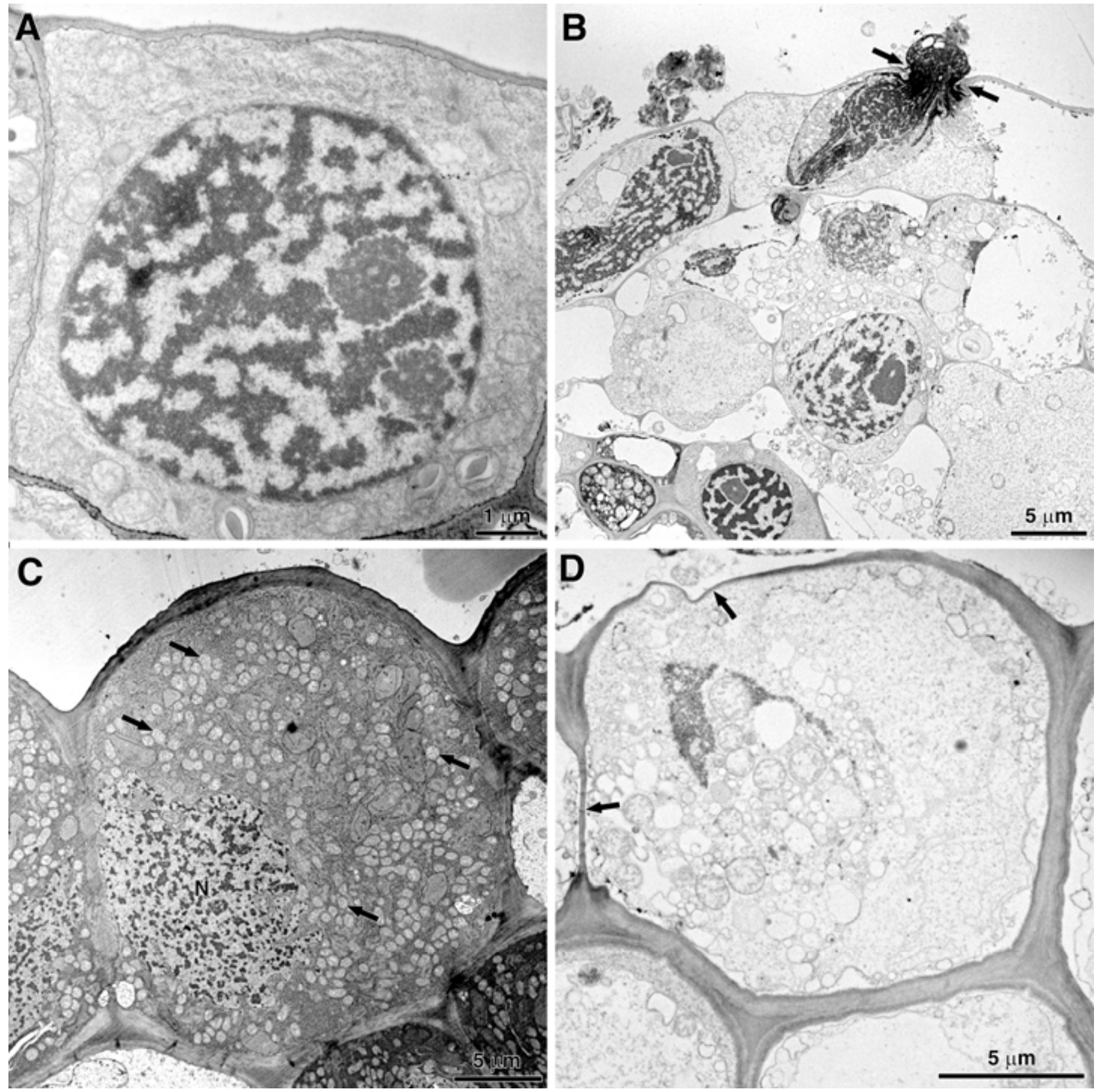

Fig. 4. Wheat epidermal cells, transmission electron microscopy. A, Typical epidermal cell found at the base of the leaf sheath where Hessian fly larvae attack. This cell type was present in both resistant and susceptible plants free of Hessian fly larvae. B, Susceptible Type One epidermal cell with a ruptured tangential wall (arrows) and degraded cell contents spilling onto the leaf surface. C, Susceptible Type Two epidermal cell, an induced nutritive cell of the larval-attacked susceptible wheat genotype. Note characteristics of a nutritive cell, including the shape of the nucleus $(\mathrm{N})$ and dense cytoplasm with numerous mitochondria (arrows) and small vacuoles. D, Susceptible Type Three induced nutritive cell that has degraded contents and thinned walls (arrows). 
time (hours, days, or weeks) to achieve their manipulation of the plant $(1,29,76,87)$.

Attack on resistant plants also differed from attack on susceptible plants by showing two previously unseen cell types (Table 3). Resistant Cell Type One (Table 3) appears healthy, activated for synthesis and secretion, with a proliferation of ER and Golgi bodies, and vesicles lined up next to the Golgi (Figs. 5 and 6). In contrast, Resistant Cell Type Two (Table 3) appears to be dying (Fig. 5A, cell on extreme right under the larva). Death is suggested by extreme plasmolysis (a large separation between the wall and the plasma membrane) and the breakdown of cytoplasmic contents. Neither of these cell types was observed in resistant plants free of larvae.

A reinforced wall is a shared feature of Resistant Type One and Resistant Type Two cells. Wall reinforcement has been studied relatively little for insects, perhaps because the cell wall is not a significant barrier for insects with large mandibles or sharp stylets $(7,75)$. Hückelhoven $(42)$ proposed that plants have at least three options for reinforcing the cell wall against pathogen attack: (i) inhibiting the enzymes that are secreted by pathogens to degrade the wall, (ii) remodeling the wall both structurally and chemically at sites of attempted penetration, and (iii) placing toxic chemicals in the wall to kill the attacking pathogen. Protecting the tangential cell wall against Hessian fly attack could involve all three. An epidermal cell directly attacked by the larva needs to remodel its tangential wall to repair the physical damage done by the larval mandible (Figs. 1 and 2). At the same time, the epidermal cell must counteract the effectors produced by the salivary glands of the Hessian fly larva $(12,79)$. Mesophyll cells adjacent to epidermal cells also respond (Figs. 5 and 6). This may help to create a barrier between dead cells that are lost forever and living cells that can be saved. Evidence for the placement of plant toxins in the wall comes from biochemical studies of Hessian fly antioxidant defense responses (60). Candidates for plant toxins are lectins. Genes coding for lectins (e.g., $H f r-1)$ are strongly upregulated in 49 -resistant wheat within $24 \mathrm{~h}$ of Hessian fly attack $(81,82)$. Toxins could be part of the granular material that appears in the paramural space between the wall and plasma membrane or within the "pockets" located within the wall matrix (Fig. 6B).

Subcellular features of Resistant Type One cells suggest how the cell reinforces its wall (Table 3). The prominence of the ERGolgi complex in these cells suggests active synthesis and secretion of materials, with numerous vesicles then delivering materials to the wall. The need for rapid delivery of vesicles to the cell periphery may explain the membrane masses that were observed directly beneath the outer cell wall (Fig. 6D), although membrane masses also can result when the plasma membrane becomes smaller as a result of plasmolysis (64). Accumulation of membranes at the cell periphery indicates an imbalance in the epidermal cell, with delivery of membrane to the periphery (exocytosis) outstripping retrieval and recycling of membrane back into the cytoplasm (endocytosis).

Several of the subcellular features shown by Resistant Type One cells also have been observed during plant resistance to fungi; for example, barley Mlo resistance to the biotrophic powdery mildew fungus, Blumeria graminis f. sp. hordei $(2,3,9$, $33,42,46,53,74)$. Here, it has been shown that secretory vesicles originate from the ER-Golgi complex and are guided by actin microfilaments to a specific destination at the periphery, where they join the plasma membrane and deliver their cargo. Delivery of cargo to the periphery makes sense because the Golgi bodies synthesize the wall's polysaccharides, while a region near the plasma membrane needs materials to synthesize the wall's cellulose microfibrils $(43,50)$. The various types of vesicles that have been observed $(2,3)$ are thought to carry different cargo (e.g., defense molecules, cell wall components, or possibly chemicals that protect against cell death) (51). The heterogeneous nature of wall architecture within a single cell (43) supports the idea that materials secreted by the ER-Golgi complex can be targeted to distinct sites, such as the tangential wall.

In contrast to Resistant Type One cells, Resistant Type Two cells (Table 3) were either dead or dying. Dying cells suggest a hypersensitive response (HR), a well-known mechanism of resistance to biotrophic pathogens $(1,40,48)$, which also has been
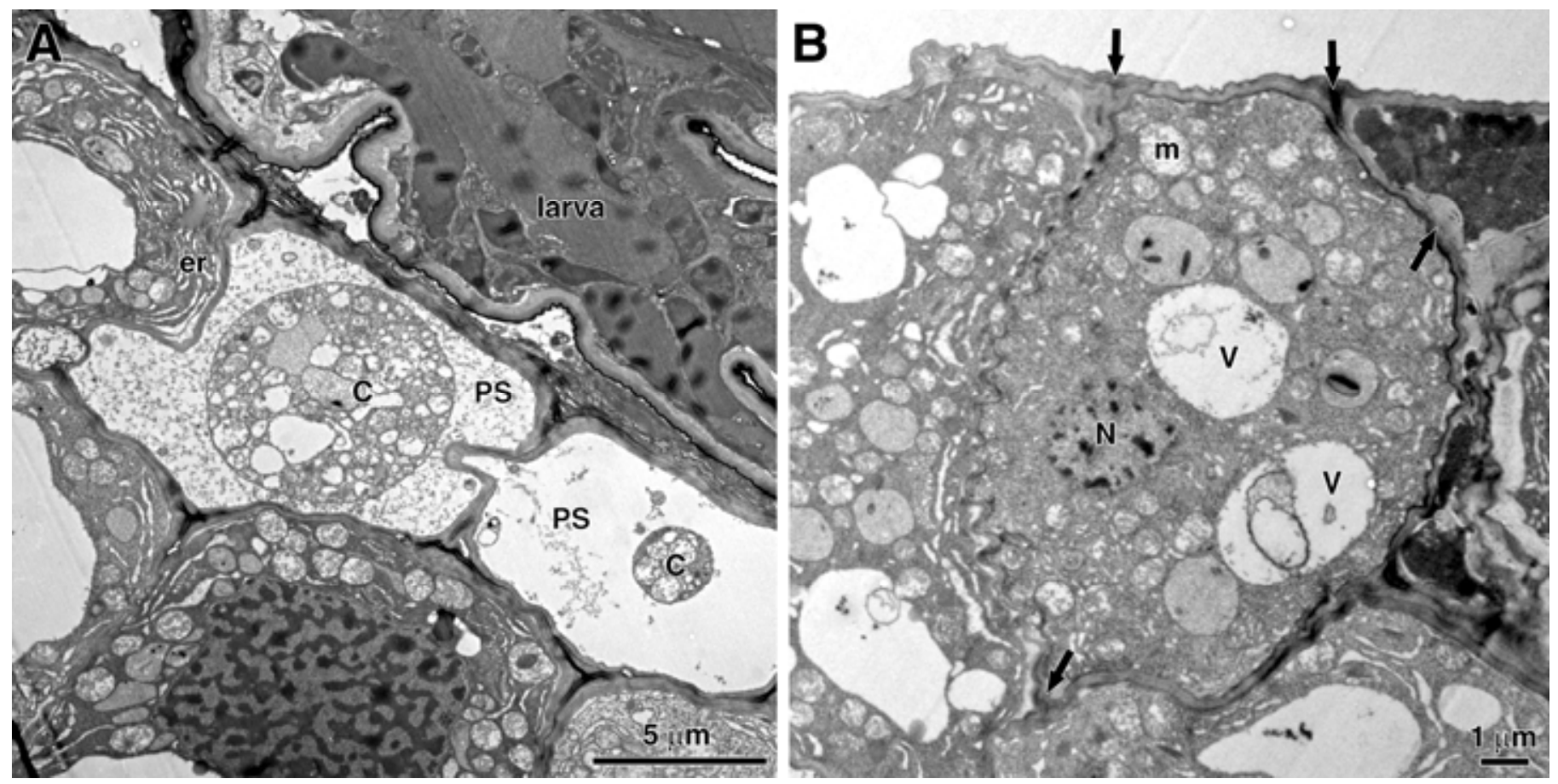

Fig. 5. Epidermal cells of resistant-genotype wheat plants infested by Hessian-fly larvae, transmission electron microscopy. A, Hessian-fly larva and three adjacent epidermal cells. The cell at the right and the cell in the middle are typical Resistant Type Two cells and appear to be dying. Note the thickened tangential cell wall and the large paramural space (PS) between the cell wall and the degraded cytoplasm (C). The adjacent epidermal cell shown at the upper left is a typical Resistant Type One cell and appears healthy. Note its thickened tangential cell wall and the proliferation of endoplasmic reticulum (er) with swollen cisternae. B, Resistant Type One cell. Note the nucleus (N), swollen mitochondria (m), vacuoles (V), and thickened tangential cell wall (arrows). 

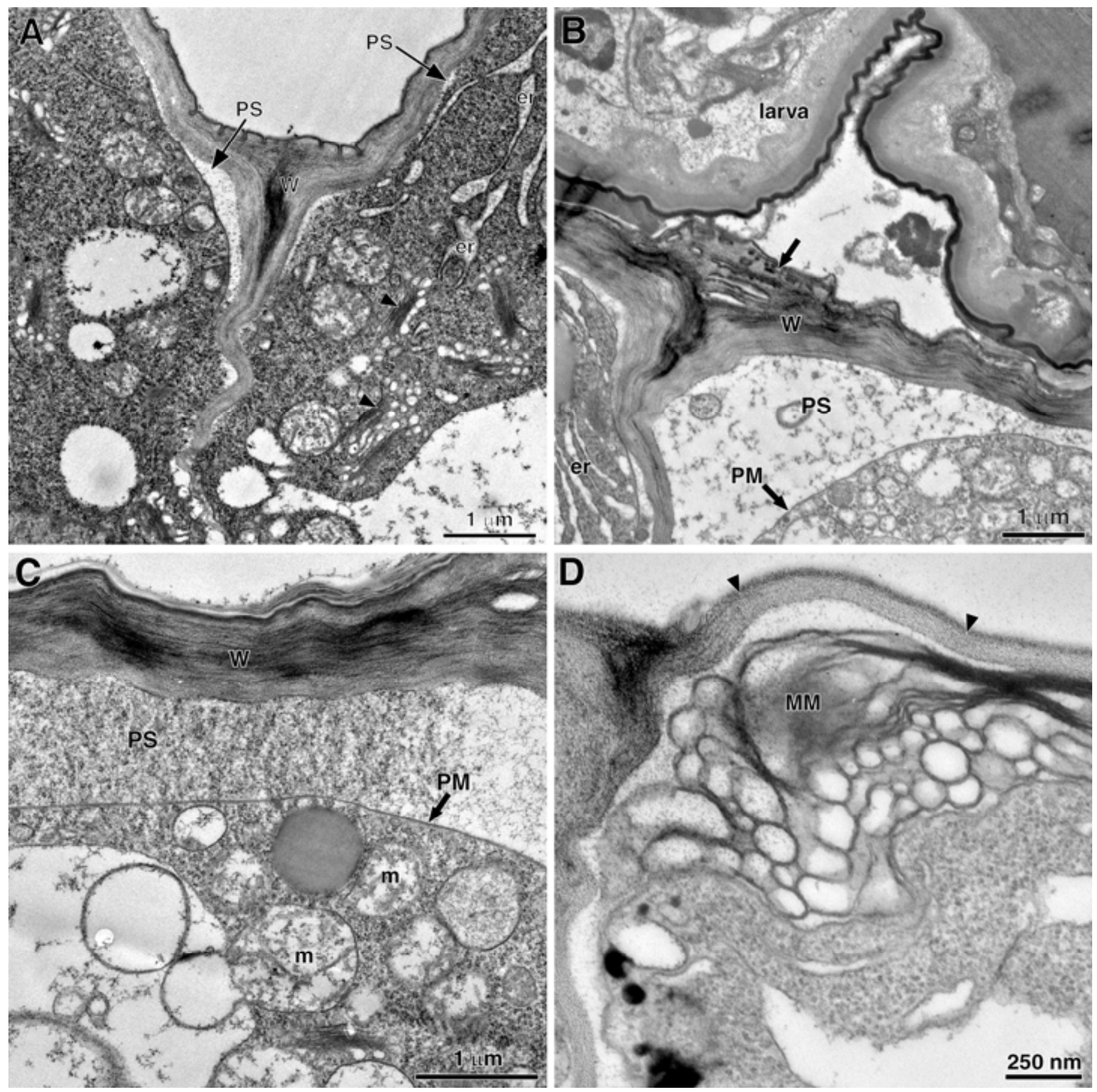

Fig. 6. Details of Resistant Type One epidermal cells in resistant-genotype wheat attacked by Hessian-fly larvae, transmission electron microscopy. A, Small paramural space (PS, arrows) between the thickened cell wall (W) and plasma membrane, Golgi (arrowheads) with their associated vesicles, and swollen endoplasmic reticulum (er). B, Thickened cell wall (W) with pockets of material found within the wall and penetrating between adjacent epidermal cells (arrow). Accumulated material is found in the paramural space (PS) between the cell wall and the plasma membrane (PM). In the adjacent epidermal cell at the lower left, note the swollen endoplasmic reticulum (er). C, Swollen mitochondria $(\mathrm{m})$ and vacuoles within a relatively dense cytoplasm. Material has accumulated in the paramural space (PS) between the plasma membrane (PM, arrow) and the outer cell wall (W). D, Accumulation of membranous material (MM) directly below the outer tangential wall (arrowheads) of a cell with dense cytoplasm.

invoked as a mechanism of resistance to gall midges and eriophyid mites $(19,20,41,63,84,85)$. However, recent studies of willow resistance have cast doubt on whether cell death is actually what kills the gall midge larva $(41,63)$. For resistance to the Hessian fly, leaf-surface depressions observed near larval attack sites have been taken as evidence for HR, even though similar depressions were seen on susceptible plants (32). The lack of an oxidative burst during Hessian-fly attack of $\mathrm{H}$-genecontaining wheat (28) has been taken as evidence that HR is not important for plant resistance to the Hessian fly. However, HR can occur via responses other than the oxidative burst, as has been demonstrated for plant-pathogen interactions $(13,39)$. We can only speculate that, if HR is part of resistance to Hessian fly, it is limited in scale, occurring only in the first cells that are directly attacked by the larval mandibles. In such cells, HR may be preceded by fortification of the cell wall (Fig. 5B).

A benefit of the dramatic plasmolysis associated with cell death (61) could be the "lockdown" of a molecule that is necessary for the creation of the nutritive tissue but only present in epidermal cells directly attacked by a Hessian fly larva. The need for such a 
TABLE 4. Body length of Hessian fly larvae on susceptible and $H$-gene-containing resistant wheat

\begin{tabular}{|c|c|c|c|c|c|c|}
\hline \multirow[b]{2}{*}{ Wheat } & \multirow[b]{2}{*}{ Body $(\mu \mathrm{m})^{\mathrm{a}}$} & \multicolumn{4}{|c|}{ Body length $(\mu \mathrm{m})$ at attack sites $(\text { mean } \pm \mathrm{SE})^{\mathrm{b}}$} & \multirow[b]{2}{*}{ ANOVA (time) $)^{\mathrm{c}}$} \\
\hline & & $6 \mathrm{~h}$ & $30 \mathrm{~h}$ & $54 \mathrm{~h}$ & $78 \mathrm{~h}$ & \\
\hline Susceptible 'Newton' & $463 \pm 6(n=16)$ & $484 \pm 3(n=77)$ & $559 \pm 5(n=61)$ & $761 \pm 15(n=48)$ & $959 \pm 29(n=69)$ & $\mathrm{F}_{3,251}=108.71 * P<0.001$ \\
\hline Resistant $H 6$ & $465 \pm 6(n=12)$ & $457 \pm 4(n=68)$ & $454 \pm 5(n=55)$ & $520 \pm 18(n=72)$ & $484 \pm 23(n=51)$ & $\mathrm{F}_{3,242}=5.04 * P<0.002$ \\
\hline Resistant $H 9$ & $460 \pm 6(n=16)$ & $454 \pm 4(n=58)$ & $439 \pm 4(n=73)$ & $420 \pm 6(n=56)$ & $416 \pm 5(n=55)$ & $\mathrm{F}_{3,238}=125.67 * P<0.001$ \\
\hline Resistant $H 13$ & $466 \pm 5(n=17)$ & $461 \pm 5(n=39)$ & $454 \pm 5(n=60)$ & $411 \pm 4(n=68)$ & $411 \pm 5(n=61)$ & $\mathrm{F}_{3,224}=30.56 P<0.001$ \\
\hline Resistant $H 26$ & $452 \pm 6(n=16)$ & $447 \pm 4(n=62)$ & $432 \pm 5(n=49)$ & $409 \pm 5(n=41)$ & $415 \pm 7(n=68)$ & $\mathrm{F}_{3,189}=92.85^{*} P<0.001$ \\
\hline ANOVA (genotype) ${ }^{\mathrm{d}}$ & $\begin{array}{c}\mathrm{F}_{4,72}=1.07 \\
\mathrm{NS}\end{array}$ & $\begin{array}{c}\mathrm{F}_{4,299}=17.63 \\
P<0.001\end{array}$ & $\begin{array}{c}\mathrm{F}_{4,293}=112.25^{*} \\
P<0.001\end{array}$ & $\begin{array}{c}\mathrm{F}_{4,280}=143.04 * \\
P<0.001\end{array}$ & $\begin{array}{c}\mathrm{F}_{4,275}=185.81 * \\
P<0.001\end{array}$ & \\
\hline
\end{tabular}

a Body length $(\mu \mathrm{m})$ after eclosion from the egg.

b $\mathrm{SE}=$ standard error.

${ }^{c}$ Effect of time. Asterisk (*) indicates $F$ values are from Welch analysis of variance (ANOVA).

${ }^{\mathrm{d}}$ Effect of genotype; NS = not significant.

molecule, as well as cell-to-cell movement of the molecule, is suggested by the fact that much of the nutritive tissue lies in the mesophyll layer (Fig. 3). The larva's mandibles are far too small to reach mesophyll cells. Plasmolysis has been shown to prevent the cell-to-cell movement of viruses by severing or blocking the cell-to-cell connections formed by plasmodesmata (70). Plasmolysis can occur on a large scale and be irreversible or can occur on a smaller scale and be reversed, with the cell then surviving (64). In our study, the small separation between the cell wall and plasma membrane observed in Resistant Type One cells suggests some degree of reversible plasmolysis (Fig. 6) whereas the larger separation observed in Resistant Type Two cells (Fig. 5A) suggests that irreversible plasmolysis also occurs. It is interesting that the opposite of plasmolysis (i.e., attachment or adhesion of the membrane to the cell wall) is a requirement for wall-associated resistance to fungal pathogens in pea (59).

Unfortunately, we lack the tools to prove that death only occurs in the first cells that are directly attacked by the Hessian fly larva. Unlike fungi and nematodes that leave a physical structure identifying precisely where attack has occurred $(2,3,87)$, the Hessianfly larva leaves only a tiny hole (Figs. 1 and 2) that is hard to find. In the future, identification of the products of Hessian fly avirulence genes (79) may allow marking of the epidermal cells that are directly attacked by the larval mandibles, making possible imaging studies like those that have provided fine details of subcellular responses to fungal attack $(2,3)$.

The four $\mathrm{H}$-gene-containing wheat genotypes showed similar resistance responses (Table 2) (i.e., reinforced walls, as well as Resistant Type One and Type Two cells). The four $H$-genecontaining genotypes also failed to show susceptible responses. On the other hand, the larvae that attacked the four genotypes were not identical in their growth responses. During the first $78 \mathrm{~h}$ at attack sites, larvae on $H 9, H 13$, and $H 26$ became progressively smaller (Table 4 ) whereas larvae on $H 6$ initially grew by $14 \%$ but then failed to grow further (Table 4). By $78 \mathrm{~h}$, larvae on susceptible plants had doubled in size. This raises the question of whether the resistance responses of $H 6$ are delayed relative to those of $H 9, H 13$, and $H 26$. Such a delay would not have been seen in comparative imaging studies because samples were taken at $78 \mathrm{~h}$, a time when resistance had reached effective levels for all four resistant genotypes. Two other studies $(4,34)$ have found that $H 6$ responds more like a susceptible plant during the first 2 days of larval attack but thereafter responds like resistant $H 9$ - or H13containing plants. Delays in resistance responses also have been observed within the allelic series of barley Mla gene-for-gene resistance to powdery mildew (10).

In conclusion, in $H$-gene-containing wheat plants attacked by Hessian-fly larvae, induced resistance responses replaced induced susceptible responses. The resistance that is induced has features that resemble vesicle-associated penetration resistance against pathogens $(2,3,33,74)$. Our observations raise the possibility that penetration resistance also acts against other small arthropods, especially those that target the cell wall as a first step toward inducing susceptibility. These arthropods include (78) other phytophagous gall midges (hundreds of species), gall-forming eriophyid mites (hundreds of species), and gall-forming insects other than gall midges (e.g., cynipid wasps and thrips [thousands of species]).

\section{ACKNOWLEDGMENTS}

Hessian-fly voucher specimens have been deposited in the North Dakota State University Insect Reference Collection, Fargo. Research was supported by the National Research Initiative of the USDA Cooperative State Research, Education and Extension Service, grant number 2005-35302-16254. We thank M. Heath (now retired from the University of Toronto) for helping us decipher subcellular responses and introducing us to important literature on plant-pathogen interactions; R. Panstruga (Max Planck Institute for Plant Breeding Research), L. Walling (University of California, Riverside), C. Williams (USDA-ARS, Purdue University), R. Shukle (USDA-ARS, Purdue University), M.-S. Chen (USDA-ARS, Kansas State University), and J. Stuart (Purdue University) for providing comments on an early draft of the manuscript; our editor and two reviewers for suggestions that much improved the manuscript; S. Cambron (USDA-ARS, Purdue University) for providing Hessian fly when our supplies were low; and J. Schultz (University of Missouri) for pointing out B. McClintock's interest in plant galls.

\section{LITERATURE CITED}

1. Agrios, G. 1997. Plant Pathology, 4th ed. Academic Press, San Diego.

2. An, Q., Ehlers, K., Kogel, K. H., van Bel, A. J. E., and Hückelhoven, R. 2006. Multivesicular compartments proliferate in susceptible and resistant MLA12-barley leaves in response to infection by the biotrophic powdery mildew fungus. New Phytol. 172:563-576.

3. An, Q., Huckelhoven, R., Kogel, K. H., and van Bel, A. J. E. 2006. Multivesicular bodies participate in a cell wall-associated defence response in barley leaves attacked by the pathogenic powdery mildew fungus. Cell Microbiol. 8:1009-1019.

4. Anderson, K. G., and Harris, M. O. 2006. Does $R$ gene resistance allow wheat to prevent plant growth effects associated with Hessian fly (Diptera: Cecidomyiidae) attack? J. Econ. Entomol. 99:1842-1853.

5. Anderson, K. G., and Harris, M. O. 2008. Leaf growth signals the onset of effective plant resistance against Hessian fly larvae. Entomol. Exp. Appl. 128:184-195.

6. Bent, A. F., and Mackey, D. 2007. Elicitors, effectors and $R$ genes: The new paradigm and a lifetime supply of questions. Annu. Rev. Phytopathol. 45:399-436.

7. Bernays, E. A., and Chapman, R. F. 1994. Host-Plant Selection by Phytophagous Insects. Chapman and Hall, New York.

8. Berzonsky, W. A., Shanower, T. G., Lamb, R. J., McKenzie, R. I. H., Ding, H., Harris, M. O., Peairs, F., Haley, S., Porter, D., Ratcliffe, R. H., Ohm, H., and Patterson, F. 2003. Breeding wheat for resistance to insects. Plant Breed. Rev. 22:221-297.

9. Bhat, R. A., Miklis, M., Schmelzer, E., Schulze-Lefert, P., and Panstruga, R. 2005. Recruitment and interaction dynamics of plant penetration resistance components in a plasma membrane microdomain. Proc. Natl. Acad. Sci. USA 102:3135-3140.

10. Boyd, L. A., Smith, P. H., Foster, E. M., and Brown, J. K. M. 1995. The effects of allelic variation at the Mla resistance locus in barley on the 
early development of Erysiphe graminis f. sp. hordei and host responses. Plant J. 7:959-968.

11. Bronner, R. 1992. The role of the nutritive tissue in the nutrition of cynipids and cecidomyiids. Pages 118-141 in: Biology of Insect-Induced Galls. J. Shorthouse and O. Rohfritsch, eds. Oxford University Press, New York.

12. Chen, M. S., Fellers, J. P., Stuart, J. J., Reese, J. C., and Liu, X. M. 2004. A group of related cDNAs encoding secreted proteins from Hessian fly [Mayetiola destructor (Say)] salivary glands. Insect Mol. Biol. 13:101108.

13. Christopher-Kozjan, R., and Heath, M. C. 2003. Cytological and pharmacological evidence that biotrophic fungi trigger cell death execution processes in host and nonhost cells during the hypersensitive response. Physiol. Mol. Plant Pathol. 62:265-275.

14. Dangl, J. L., and McDowell, J. M., 2006. Two modes of pathogen recognition by plants. Proc. Natl. Acad. Sci. USA 103:8575-8576.

15. Dreger-Jauffret, F., and Shorthouse, J. D. 1992. Diversity of gall-inducing insects and their galls. Pages 8-33 in: Biology of Insect-Induced Galls. J. Shorthouse and O. Rohfritsch, eds. Oxford University Press, New York.

16. El Bouhssini, M., Chen, M., Lhaloui, S., Zharmukhamedova, G., and Rihawi, F. 2008. Virulence of Hessian fly (Diptera: Cecidomyiidae) in the Fertile Crescent. J. Appl. Entomol. 133:381-385.

17. Ellis, J. G., Dodds, P. N., and Lawrence, G. J. 2007. Flax rust resistance gene specificity is based on direct resistance-avirulence protein interactions. Annu. Rev. Phytopathol. 45:289-306.

18. Erlich, P. R., and Raven, P. H. 1964. Butterflies and plants: A study of coevolution. Evolution 18:586-608.

19. Fernandes, G. W. 1990. Hypersensitivity: A neglected plant resistance mechanism against insect herbivores. Environ. Entomol. 19:1173-1182.

20. Fernandes, G. W., and Negreiro, D. 2001. The occurrence and effectiveness of hypersensitive reaction against galling herbivores across host taxa. Ecol. Entomol. 26:46-55.

21. Flor, H. H. 1955. Host-parasite interactions in flax-its genetics and other implications. Phytopathology 45:680-685.

22. Flor, H. H. 1956. The complementary genic systems in flax and flax rust. Adv. Genet. 8:29-54.

23. Fraenkel, G. 1959. The raison d'être of secondary plant substances. Science 129:1466-1470.

24. Gagné, R. J. 1989. The Plant-feeding Gall Midges of North America. Cornell University Press, Ithaca, NY.

25. Gagné, R. J., and Hatchett, J. H. 1989. Instars of the Hessian fly (Diptera: Cecidomyiidae). Ann. Entomol. Soc. Am. 82:73-79.

26. Gallun, R. L. 1977. The genetic bases of Hessian fly epidemics. Ann. N. Y. Acad. Sci. 287:223-229.

27. Gallun, R. L., and Patterson, F. L. 1977. Monosomic analysis of wheat for resistance to Hessian fly. J. Hered. 68:223-236.

28. Giovanni, M. P., Puthoff, D. P., Nemacheck, J. A., Mittapalli, O., Saltzmann, K. D., Ohm, H. W., Shukle, R. H., and William, C. E. 2006. Gene-for-gene defense of wheat against the Hessian fly lacks a classical oxidative burst. Mol. Plant-Microbe Interact. 19:1023-1033.

29. Goethals, K., Vereecke, D., Jaziri, M., van Montagu, M., and Holsters, M. 2001. Leafy gall formation by Rhodococcus fascians. Annu. Rev. Phytopathol. 39:27-52.

30. Goggin, F. 2007. Plant-aphid interactions: Molecular and ecological perspectives. Curr. Opin. Plant Biol. 10:399-408.

31. Gould, F. 1998. Sustainability of transgenic insecticidal cultivars: Integrating pest genetics and ecology. Annu. Rev. Entomol. 43:701-726.

32. Grover, P. B. 1995. Hypersensitive response of wheat to Hessian fly. Entomol. Exp. Appl. 74:283-294.

33. Hardham, A. R., Jones, D. A., and Takemoto, D. 2007. Cytoskeleton and cell wall function in penetration resistance. Curr. Opin. Plant Biol. 10:342-348.

34. Harris, M. O., Anderson, K. G., Anderson, K. M., and Kanno, H. 2006. Proximate cues for reduced oviposition on wheat plants attacked by conspecific larvae. Environ. Entomol. 35:83-93.

35. Harris, M. O., Freeman, T. P., Rohfritsch, O., Anderson, K. G., Payne, S. A., and Moore, J. A. 2006. Virulent Hessian fly (Diptera: Cecidomyiidae) larvae induce a nutritive tissue during compatible interactions with wheat. Ann. Entomol. Soc. Am. 99:305-316.

36. Harris, M. O., Stuart, J. J., Mohan, M., Nair, S., Lamb, R. J., and Rohfritsch, O. 2003. Grasses and gall midges: Plant defense and insect adaptation. Annu. Rev. Entomol. 45:549-577.

37. Hatchett, J. H., Kreitner, G. L., and Elzinga, R. J. 1990. Larval mouthparts and feeding mechanism of the Hessian fly (Diptera: Cecidomyiidae). Ann. Entomol. Soc. Am. 83:1137-1147.

38. Hauck, P., Thilmony, R., and He, S. Y. 2003. A Pseudomonas syringae type III effector suppresses cell-wall-based extracellular defense in susceptible Arabidopsis plants. Proc. Natl. Acad. Sci. USA 100:85778582 .

39. Heath, M. C. 1998. Involvement of reactive oxygen species in the response of resistant (hypersensitive) or susceptible cowpeas to the cowpea rust fungus. New Phytol. 138:251-263.

40. Heath, M. C. 2000. Nonhost resistance and nonspecific plant defenses. Curr. Opin. Plant Biol. 3:315-319.

41. Höglund, S., Larsson, S., and Wingsle, G. 2005. Both hypersensitive and non-hypersensitive responses are associated with resistance in Salix viminalis against the gall midge Dasineura marginemtorquens. J. Exp. Bot. 56:3215-3222.

42. Hückelhoven, R. 2007. Cell wall-associated mechanisms of disease resistance and susceptibility. Annu. Rev. Phytopathol. 45:101-127.

43. Johansen, J. N., Verhettes, S., and Höfte, H. 2006. The ins and outs of plant cell walls. Curr. Opin. Plant Biol. 9:616-620.

44. Kaloshian, I., and Walling, L. L. 2005. Hemipterans as plant pathogens. Annu. Rev. Phytopathol. 43:491-521.

45. Karban, R., and Agrawal, A. A. 2002. Herbivore offense. Annu. Rev. Ecol. Syst. 33:641-664.

46. Koh, S., and Somerville, S. 2006. Show and tell: Cell biology of pathogen invasion. Curr. Opin. Plant Biol. 9:406-413.

47. Kong, L., Ohm, H. W., Cambron, S. E., and Williams, C. E. 2005. Molecular mapping determines that Hessian fly resistance gene $H 9$ is located on chromosome 1A of wheat. Plant Breed. 124:525-531.

48. Lamb, C., and Dixon, R. A. 1997. The oxidative burst in plant disease resistance. Annu. Rev. Plant Physiol. Plant Mol. Biol. 48:251-275.

49. Larson, K. C., and Whitham, T. G. 1991. Manipulation of food resources by a gall-forming aphid: The physiology of sink-source interactions. Oecologia 88:15-21.

50. Lerouxel, O., Cavalier, D. M., Liepman, A. H., and Keegstra, K. 2006. Biosynthesis of plant cell wall polysaccharides-a complex process. Curr. Opin. Plant Biol. 9:621-630.

51. Levine, A. 2002. Regulation of stress responses by intracellular vesicle trafficking? Plant Physiol. Biochem. 40:531-535.

52. Li, M., Zou, J. J., Li, M., Bilgin, D. D., Vodkin, L. O., Hartman, G. L., and Clough, S. J. 2008. Soybean defense responses to the soybean aphid. New Phytol. 179:185-195.

53. Lipka, V., and Panstruga, R. 2005. Dynamic cellular responses in plantmicrobe interactions. Curr. Opin. Plant Biol. 8:625-631.

54. Liu, X. M., Fritz, A. K., Reese, J. C., Wilde, G. E., Gill, B. S., and Chen, M. S. 2005. H9, H1O and $H 11$ compose a cluster of Hessian fly-resistance genes in the distal gene-rich region of wheat chromosome 1AS. Theor. Appl. Genet. 110:1473-1480.

55. Liu, X. M., Gill, B. S., and Chen, M. S. 2005. Hessian fly resistance gene H13 is mapped to a distal cluster of resistance genes in chromosome 6DS of wheat. Theor. Appl. Genet. 111:243-249.

56. Martinez-de Ilarduya, O., Xie, Q. G., and Kaloshian, I. 2003. Aphidinduced defense responses in Mi-1-mediated compatible and incompatible tomato interactions. Mol. Plant-Microbe Interact. 16:699708.

57. McClintock, B. 1984. The significance of responses of the genome to challenge. Science 226:792-801

58. McColloch, J. W., and Yuasa, H. 1917. Notes on the migration of the Hessian fly larvae. J. Anim. Behav. 7:307-323.

59. Mellersh, D. G., and Heath, M. C. 2001. Plasma membrane-cell wall adhesion is required for expression of plant defense responses during fungal penetration. Plant Cell 13:413-424.

60. Mittapalli, O., Neal, J. J., and Shukle, R. H. 2007. Antioxidant defense response of a galling insect. Proc. Natl. Acad. Sci. USA 104:1889-1894.

61. Mould, M. J. R., and Heath, M. C. 1999. Ultrastructural evidence of differential changes in transcription, translation, and cortical microtubules during in planta penetration of cells resistant or susceptible to rust infection. Physiol. Mol. Plant Pathol. 55:225-236.

62. Nimchuk, Z., Eulgem, T., Holt, B. F., and Dangl, J. L. 2003. Recognition and responses in the plant immune system. Annu. Rev. Genet. 37:579609.

63. Ollerstam, O., Rohfritsch, O., Höglund, S., and Larsson, S. 2002. A rapid hypersensitive response associated with resistance in the willow Salix viminalis against the gall midge Dasineura marginemtorquens. Entomol. Exp. Appl. 102:153-162.

64. Oparka, K. J. 1994. Plasmolysis: New insights into an old process. New Phytol. 126:571-591

65. Painter, R. H. 1951. Insect Resistance in Crop Plants. Macmillan, New York.

66. Panstruga, R. 2003. Establishing compatibility between plants and obligate biotrophic pathogens. Curr. Opin. Plant Biol. 6:320-326.

67. Patterson, F. L., Maas, F. B., Foster, J. E., Ratcliffe, R. H., Cambron, S., Safranski, G., Taylor, P. L., and Ohm, H. W. 1994. Registration of eight Hessian fly resistant common winter wheat germplasm lines. Crop Sci. 34:315.

68. Ratcliffe, R. H., Cambron, S. E., Flanders, K. L., Bosgue-Perez, N. A., Clement, S. L., and Ohm, H. W. 2000. Biotype composition of Hessian fly (Diptera: Cecidomyiidae) populations from the southern, midwestern 
and northwestern United States and virulence to resistance genes in wheat. J. Econ. Entomol. 93:1319-1328.

69. Refai, F. Y., Miller, B. S., Jones, E. T., and Wolfe, J. E. 1956. The feeding mechanism of Hessian fly larvae. J. Econ. Entomol. 49:182-185.

70. Roberts, A. G., and Oparka, K. J. 2003. Plasmodesmata and the control of symplastic transport. Plant Cell Environ. 26:103-124.

71. Rohfritsch, O. 1992. Patterns in gall development. Pages 102-117 in: Biology of Insect-Induced Galls. J. Shorthouse and O. Rohfritsch, eds. Oxford University Press, New York.

72. SAS Institute. 1999. JMP Version 3.2.6. SAS Institute, Cary, NC.

73. Saltzmann, K. D., Giovanini, M. P., Zheng, C., and Williams, C. E. 2008. Virulent Hessian fly larvae manipulate the free amino acid content of host wheat plants. J. Chem. Ecol. 34:1401-1414.

74. Schulze-Lefert, P. 2004. Knocking on the heaven's wall: Pathogenesis of and resistance to biotrophic fungi at the cell wall. Curr. Opin. Plant Biol. 7:377-383.

75. Schoonhoven, L. M., van Loon, J. J. A., and Dicke, M. 2005. Insect-Plant Biology. Oxford University Press, Oxford.

76. Shorthouse, J. D., and Rohfritsch, O. 1992. Biology of Insect-Induced Galls. Oxford University Press, New York.

77. Smith, C. M., and Boyko, E. V. 2006. The molecular bases of plant resistance and defense responses to aphid feeding: Current status. Entomol. Exp. Appl. 122:1-16.

78. Stone, G. N., and Schönrogge, K. 2003. The adaptive significance of insect gall morphology. Trends Ecol. Evol. 18:512-522.

79. Stuart, J. J., Chen, M. S., and Harris, M. O. 2008. Hessian fly. Pages 93102 in: Genome Mapping and Genomics in Arthropods. C. Kole and W. Hunter, eds. Springer, Berlin.

80. Stuart, J. J., and Hatchett, J. H. 1987. Morphologenesis and cytology of the salivary gland of the Hessian fly Mayetiola destructor (Diptera: Cecidomyiidae). Ann. Entomol. Soc. Am. 80:475-482.

81. Subramanyam, S., Sardesai, N., Puthoff, D. P., Meyer, J. M., Nemacheck, J. A., Gonzalo, M., and Williams, C. E. 2005. Expression of two wheat defense-response genes, $H f r-1$ and $W c i-1$, under biotic and abiotic stresses. Plant Sci. 170:90-103.

82. Subramanyam, S., Smith, D. F., Clemens, J. C., Webb, M. A., Sardesai, N., and Williams, C. E. 2008. Functional characterization of Hfr-1, a high mannose N-glycan-specific wheat lectin induced by Hessian fly larvae. Plant Physiol. 147:1412-1426.

83. Walling, L. 2000. The myriad plant responses to herbivores. J. Plant Growth Regul. 19:195-216.

84. Westphal, E. 1992. Cecidogenesis and resistance phenomena in miteinduced gall. Pages 141-156 in: Biology of Insect-Induced Galls. J. Shorthouse and O. Rohfritsch, eds. Oxford University Press, New York

85. Westphal, E., and Manson, D. C. M. 1996. Feeding effects on host plants: Gall formation and other distortions. Pages 231-242 in: Eriophyoid Mites-Their Biology, Natural Enemies and Control. E. E. Lindquist, M. W. Sabelis, and J. Bruin, eds. Elsevier Science, Amsterdam.

86. Will, T., Tjallingii, W. F., Thonnessen, A., and van Bel, A. J. E. 2007. Molecular sabotage of plant defense by aphid saliva. Proc. Natl. Acad. Sci. USA 104:10536-10541.

87. Williamson, V. M., and Gleason, C. A. 2003. Plant-nematode interactions Curr. Opin. Plant Biol. 6:327-333.

88. Wise, R. P., Moscou, M. J., Bogdanove, A. J., and Whitham, S. A. 2007. Transcript profiling in host-pathogen interactions. Annu. Rev. Phytopathol. 45:329-369.

89. Withers, T. M., Madie, C., and Harris, M. O. 1997. The influence of clutch size on survival and reproductive potential of Hessian fly, Mayetiola destructor. Entomol. Exp. Appl. 83:205-212.

90. Yu, G. T., Cai, X., Harris, M. O., Gu, Y. Q., Luo, M., and Xu, S. 2009. Saturation and comparative mapping of the genomic region harboring Hessian fly resistance gene H26 in wheat. Theor. Appl. Genet. 118:15891599.

91. Yun, M. H., Torres, P. S., Oirdi, M. E., Rigano, L. A., GonzalezLamonthe, R., Marano, M. R., Castagnaro, A. P., Dankert, M. A., Bouarab, K., and Vojnov, A. A. 2006. Xanthan induces plant susceptibility in suppressing callose deposition. Plant Physiol. 141:178-187.

92. Zhu, L., Liu, X., Jeannotte, R., Reese, J. C., Harris, M. O., Stuart, J. J., and Chen, M. S. 2008. Hessian fly attack causes dramatic shift in carbon/nitrogen metabolism in wheat. Mol. Plant-Microbe Interact. 21:70-78.

93. Zupan, J., Muth, T. R., Draper, O., and Zambryski. P. 2000. The transfer of DNA from Agrobacterium tumefaciens into plants: A feast of fundamental insights. Plant J. 23:11-28. 